\title{
Non-contiguous finished genome sequence and description of Kurthia massiliensis sp. nov.
}

\author{
Véronique Roux ${ }^{1 *}$, Khalid El karkouri ${ }^{1}$, Jean-Christophe Lagier ${ }^{1}$, Catherine Robert ${ }^{1}$ and \\ Didier Raoult'. \\ ${ }^{1}$ Aix Marseille Université, URMITE, Faculté de médecine, Aix-Marseille Université \\ * Corresponding author: Véronique Roux (veronique.roux@univ-amu.fr)
}

Keywords: Kurthia massiliensis, Firmicutes, capsule, Flagella

Kurthia massiliensis strain $\mathrm{JC} 0^{\top} \mathrm{sp}$. nov. is the type strain of $K$. massiliensis sp. nov., a new species within the genus Kurthia. This strain, whose genome is described here, was isolated from the fecal flora of a healthy patient. K. massiliensis is a Gram-positive aerobic rod. Here we describe the features of this organism, together with the complete genome sequence and annotation. The 3,199,090 bp long genome contains 3,240 protein-coding genes and 86 RNA genes, including between 3 and 4 rRNA genes.

Abbreviations: EMBL: European Molecular Biology Laboratory

\section{Introduction}

Kurthia massiliensis strain JC30 ${ }^{\mathrm{T}}$ (CSUR $141^{\mathrm{T}}=$ DSM 24639T) is the type strain of $K$. massiliensis sp. nov. This bacterium is a Gram-positive, strictly aerobic rod that is capsulated, and motile by peritrichous flagella. This organism was originally isolated from the stool of a healthy Senegalese patient as part of a "culturomics" study aimed at cultivating all species within human feces, individually.

Currently, "the gold standard" for defining bacterial species is DNA-DNA hybridization [1]. But this method is time-consuming and the interlaboratory reproducibility is poor. Fortunately, the development of PCR and next-generation sequencing technologies have led to reliable and reproducible $16 \mathrm{~S}$ rRNA comparison methods with generally agreed upon cutoff values that enable the taxonomic classification of new species for many bacterial genera [2]. To describe new bacterial taxa, the use of a polyphasic approach was proposed [3] that includes their genome sequence, MALDI-TOF spectrum and main phenotypic characteristics (habitat, Gram-stain reaction, cultivation conditions, cell wall structure and metabolic characteristics).

The genus Kurthia was created in 1885 by Trevisan [4] in honor of Kurth who described the first species, Bacterium zopfii, isolated from the intestinal contents of chickens. As the stool samples had been stored at room temperature and the bacteria were strictly aerobic, it was assumed that the samples were contaminated by Kurthia, which multiplied during storage. The name Kurthia was first published in the seventh edition of Bergey's Manual of Determinative Bacteriology [5] and was included in the Approved Lists of Bacterial Names [6]. Currently, Kurthia includes 3 species: K. zopfii, K. gibsonii [7] and K. sibirica [8]. The bacteria are members of the phylum Firmicutes, and the family Planococcaceae. There is no evidence of pathogenicity.

Here we present a summary classification and a set of features for $K$. massiliensis sp. nov. strain $\mathrm{JC}^{\mathrm{T}} \mathrm{T}^{\mathrm{T}}$ together with the description of the complete sequencing and annotation of its genome. These characteristics support the circumscription of the species $K$. massiliensis.

\section{Classification and features}

A stool sample was collected from a healthy 16year-old male Senegalese volunteer patient living in Dielmo (a rural village in the Guinean-Sudanian zone in Senegal), who was included in a research protocol. The patient gave an informed and signed consent, and the agreement of the National Ethics Committee of Senegal and the local ethics committee of the IFR48 (Marseille, France) were obtained under agreement 09-022. The fecal specimen was preserved at $-80^{\circ} \mathrm{C}$ after collection and sent to Marseille. Strain JC30 (Table 1) was isolated in 
January 2011 by aerobic cultivation on $5 \%$ sheep blood-enriched Columbia agar (BioMerieux). This strain exhibited a $96.9 \%$ nucleotide sequence similarity with $K$ gibsonii, the phylogenetically closest validated Kurthia species (Figure 1). This value was lower than the $97 \% 16 \mathrm{~S}$ rRNA gene sequence threshold to delineate a new species without carrying out DNA-DNA hybridization recommended by the report of the ad hoc committee on reconciliation of approaches to bacterial systematics [2]. Stackebrandt and Ebers proposed to increase this value to $98.7 \%$ [21].

Table 1. Classification and general features of Kurthia massiliensis strain $\mathrm{JC}^{\mathrm{C}} 30^{\top}$ according to the MIGS recommendations [9]

\begin{tabular}{|c|c|c|c|}
\hline MIGS ID & Property & Term & Evidence code $^{a}$ \\
\hline & \multirow{8}{*}{ Current classification } & Domain Bacteria & TAS [10] \\
\hline & & Phylum Firmicutes & TAS $[11,12]$ \\
\hline & & Class Bacilli & TAS $[13,14]$ \\
\hline & & Order Bacillales & TAS $[6,15]$ \\
\hline & & Family Planococcaceae & TAS $[6,16]$ \\
\hline & & Genus Kurthia & TAS $[4,6,17,18]$ \\
\hline & & Species Kurthia massiliensis & IDA \\
\hline & & Type strain $\mathrm{JC}^{\mathrm{C}} 3 \mathrm{O}^{\top}$ & IDA \\
\hline & Gram stain & Positive & IDA \\
\hline & Cell shape & Coccobacilli & IDA \\
\hline & Motility & Motile by peritrichous flagella & IDA \\
\hline & Sporulation & Nonsporulating & IDA \\
\hline & Temperature range & Mesophile & IDA \\
\hline & Optimum temperature & $37^{\circ} \mathrm{C}$ & IDA \\
\hline MIGS-6.3 & Salinity & Growth in $\mathrm{BHI}$ medium $+3 \% \mathrm{NaCl}$ & IDA \\
\hline \multirow[t]{3}{*}{ MIGS-22 } & Oxygen requirement & Aerobic & IDA \\
\hline & Carbon source & Unknown & NAS \\
\hline & Energy source & Unknown & NAS \\
\hline MIGS-6 & Habitat & Human gut & IDA \\
\hline \multirow[t]{3}{*}{ MIGS-15 } & Biotic relationship & Free living & IDA \\
\hline & Pathogenicity & Unknown & NAS \\
\hline & Biosafety level & 2 & \\
\hline MIGS-14 & Isolation & Human feces & \\
\hline MIGS-4 & Geographic location & Senegal & IDA \\
\hline MIGS-5 & Sample collection time & September 2010 & IDA \\
\hline MIGS-4.1 & Latitude & 13.7167 & IDA \\
\hline MIGS-4.1 & Longitude & 16.4167 & IDA \\
\hline MIGS-4.3 & Depth & Surface & IDA \\
\hline MIGS-4.4 & Altitude & $51 \mathrm{~m}$ above sea level & IDA \\
\hline
\end{tabular}

Evidence codes - IDA: Inferred from Direct Assay; TAS: Traceable Author Statement (i.e., a direct report exists in the literature); NAS: Non-traceable Author Statement (i.e., not directly observed for the living, isolated sample, but based on a generally accepted property for the species, or anecdotal evidence). These evidence codes are from the Gene Ontology project [19]. If the evidence is IDA, then the property was directly observed for a live isolate by one of the authors or an expert mentioned in the acknowledgements. 


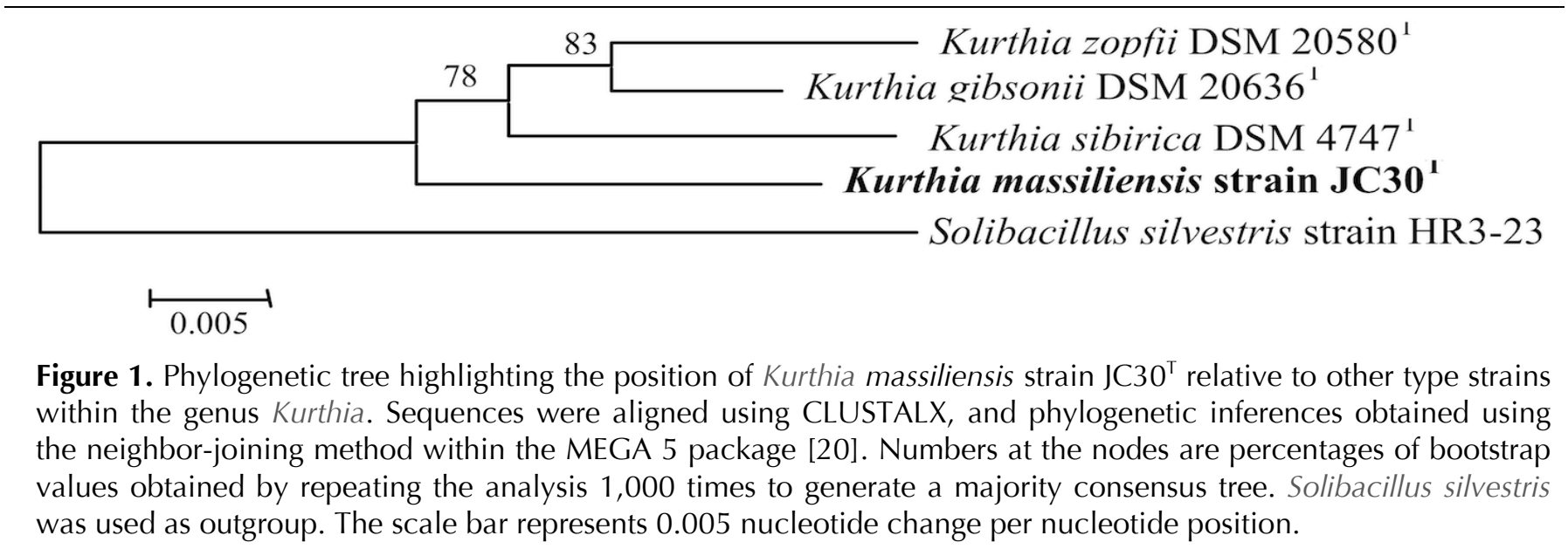

Surface colonies were observed on sheep blood agar (bioMérieux) after $24 \mathrm{~h}$ aerobic incubation at $37^{\circ} \mathrm{C}$. The colonies of strain $\mathrm{JC}^{\mathrm{T}} \mathrm{T}^{\mathrm{T}}$ were circular, greyish/yellowish, shiny, curved and smooth, 2-5 $\mathrm{mm}$ in diameter. Gram staining showed Grampositive coccobacilli (Figure 2).

Different growth temperatures $(25,30,37,45,50$ and $55^{\circ} \mathrm{C}$ ) were tested. Growth occurred between $25^{\circ} \mathrm{C}$ and $55^{\circ} \mathrm{C}$, and optimal growth was observed between $25^{\circ} \mathrm{C}$ and $50^{\circ} \mathrm{C}$. Growth of the strain was tested under aerobic atmosphere, in the presence of $5 \% \quad \mathrm{CO}_{2}$, and under anaerobic and microaerophilic atmospheres, which were created using GENbag anaer and GENbag microaer (bioMérieux), respectively. The strains were aerobic but also grew under microaerophilic conditions and in the presence of $5 \% \mathrm{CO}_{2}$. Growth does not occur under anaerobic conditions. $\mathrm{NaCl}$ tolerance of strain JC30 ${ }^{\mathrm{T}}$ was determined on Difco ${ }^{\mathrm{TM}}$ Brain Heart Infusion Agar plates (Becton Dickinson). The powder was supplemented with $\mathrm{NaCl}$ (Euromedex) to obtain the tested concentrations $(0.5,1,2,3,510,15 \%$, w/v). Growth occurred between $0.5-5 \% \mathrm{NaCl}$ but the optimum growth was between $0.5-3 \% \mathrm{NaCl}$. Growth in the range of $\mathrm{pH}$ 5.0-10.0 was tested using BBLTM Brain Heart Infusion (Becton Dickinson). pH tolerance revealed that growth could occur over a range of pH 6.0 - 9.0 with optimal growth between $\mathrm{pH} 7.0$ 9.0 .

The size and ultrastructure of cells were determined by negative staining transmission electron microscopy. The rods were 0.9-2.4 $\mu \mathrm{m}$ long and 0.6-1.8 $\mu \mathrm{m}$ wide (Figure 3). Peritrichous flagella were observed. Capsule presence was determined by India ink stain and after bacteria embedding in Epon 812 resin and observation by transmission electron microscopy (Figures 4 and 5). Strain $\mathrm{JC}^{\mathrm{T}}{ }^{\mathrm{T}}$ exhibited catalase activity but no oxidase activity. Api ZYM, Api 20NE (BioMérieux) were used to study biochemical characters [Table 2].

Analysis of respiratory quinones by HPLC was carried out by the Identification Service and $\mathrm{Dr}$ Brian Tindall, DSMZ, Braunschweig, Germany. Respiratory lipoquinones were extracted from $100 \mathrm{mg}$ of freeze dried cell material as described by Tindall $[22,23]$. Respiratory lipoquinones were separated into their different classes (menaquinones and ubiquinones) by thin layer chromatography on silica gel, using hexane:terbutylmethylether $(9: 1 \mathrm{v} / \mathrm{v})$ as solvent. UV absorbing bands corresponding to menaquinones or ubiquinones were removed from the plate and further analyzed by HPLC with detection at 269 $\mathrm{nm}$. The only respiratory quinone for strain JC30 ${ }^{\mathrm{T}}$ was MK-7 (100\%). Preparation and determination of cellular fatty acids were carried out by following the procedures given for the Sherlock Microbial identification System (MIDI). The major fatty acids were $\mathrm{C}_{15: 0}$ iso $68.04 \%$ and $\mathrm{C}_{15: 0}$ anteiso $16.92 \%$. Polar lipids were extracted from $100 \mathrm{mg}$ of freeze dried cell material using a chloroform:methanol:0.3\% aqueous $\mathrm{NaCl}$ mixture 1:2:0.8 (v/v/v) (modified after [24]). The extraction solvent was stirred overnight and the cell debris pelleted by centrifugation. Polar lipids were recovered into the chloroform phase by adjusting the chloroform:methanol:0.3\% aqueous $\mathrm{NaCl}$ mixture to a ratio of 1:1:0.9 (v/v/v). Polar lipids were separated as previously described [25]. The polar lipids present were diphosphatidylglycerol, phosphatidylglycerol, phosphatidylethanolamine, phospholipid 1. The peptidoglycan of strain JC30 was isolated as described by Schleifer [26]. 
Analysis was carried out as previously described $[26,27]$ with the modification that TLC on cellulose was used rather than paper chromatography. Quantitative analysis of amino acids was performed following derivatization by gas chromatography and gas chromatography / mass spectrometry (320-MS Quadrupole GC/MS, Varian) [28]. K. massiliensis showed the peptidoglycan type A $4 \alpha$ L-Lys $\leftarrow$ D-Glu (type A11.33 according to reference [36] ).

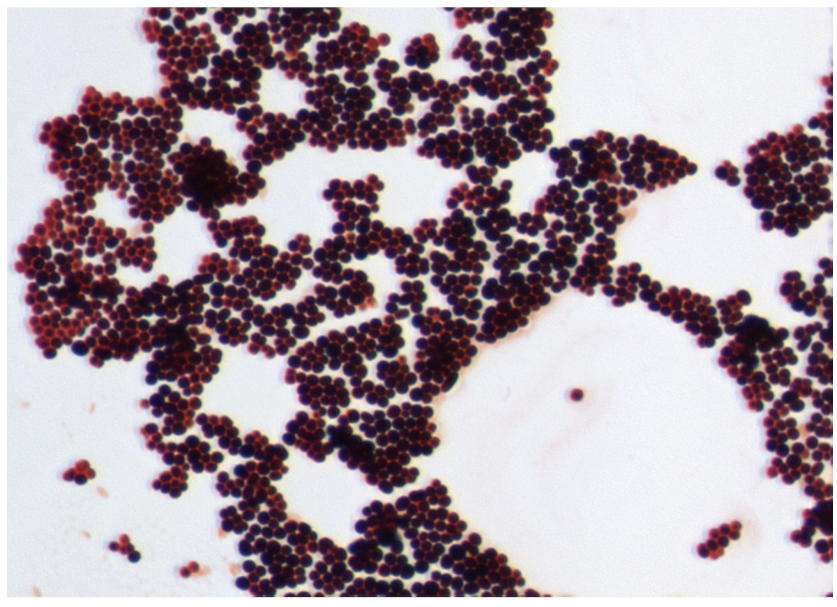

Figure 2. Gram staining of K. massiliensis strain $\mathrm{JC}^{\mathrm{C}} \mathrm{T}^{\mathrm{T}}$

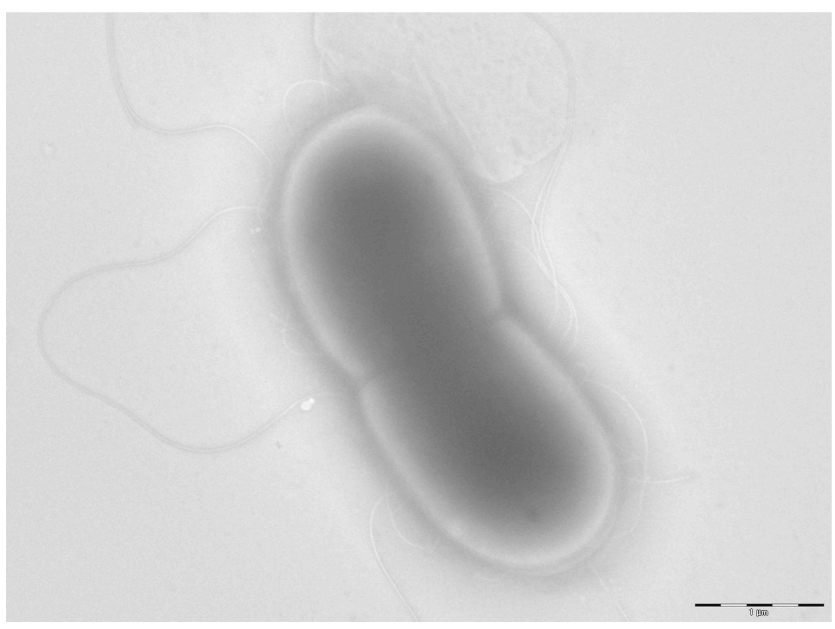

Figure 3. Transmission electron microscopy of $K$. massiliensis strain JC30, using a Morgani 268D (Philips) at an operating voltage of $60 \mathrm{kV}$.The scale bar represents $1 \mu \mathrm{m}$.

K. massiliensis was susceptible to penicillin G, amoxicillin, amoxicillin + clavulanic acid, imipenem, gentamycin, erythromycin, doxycycline, rifampicin, vancomycin, and nitrofurantoin. The organism was resistant to ceftriaxone, ciprofloxacin, sulfamethoxazole trimethoprim and metronidazole.
Matrix-assisted laser-desorption/ionization timeof-flight (MALDI-TOF) MS protein analysis was carried out. Briefly, a pipette tip was used to pick one isolated bacterial colony from a culture agar plate, and to spread it as a thin film on a MALDI-TOF target plate (Bruker Daltonics). Twelve distinct deposits were made for strain $\mathrm{JC}^{2} 0^{\mathrm{T}}$ from twelve isolated colonies and the manipulation was repeated another day. After air-drying, $1.5 \mu \mathrm{l}$ matrix solution (saturated solution of $\alpha$-cyanohydroxycinnaminic acid in $50 \%$ aqueous acetonitrile containing $2.5 \%$ trifluoroacetic acid) per spot was applied. MALDITOF MS was conducted using the Microflex LT spectrometer (Bruker Daltonics). All spectra were recorded in linear, positive ion mode. The acceleration voltage was $20 \mathrm{kV}$. Spectra were collected as a sum of 240 shots across a spot. Preprocessing and identification steps were performed using the manufacturer's parameters. The JC30 ${ }^{\mathrm{T}}$ spectra were imported into the MALDI BioTyper software (version 3.0, Bruker) and analyzed by standard pattern matching (with default parameter settings) against the main spectra of 4,108 bacteria including those from K. gibsonii, K. sibirica and K. zopfii, used as reference data, in the BioTyper database. A score enabled the identification, or not, from the tested species: a score $>2.3$ with a validly published species enabled the identification at the species level, a score $>1.7$ but $<2$ enabled the identification at the genus level; and a score $<1.7$ did not enable any identification. For strain $\mathrm{JC}^{\mathrm{T}}{ }^{\mathrm{T}}$, none of the obtained scores was $>1$, thus suggesting that our isolate was not a member of a known species. We incremented our database with the spectrum from strain $\mathrm{JC}^{\mathrm{T}}{ }^{\mathrm{T}}$ (Figure 6). The spectrum was made available online in our free-access URMS database [29].

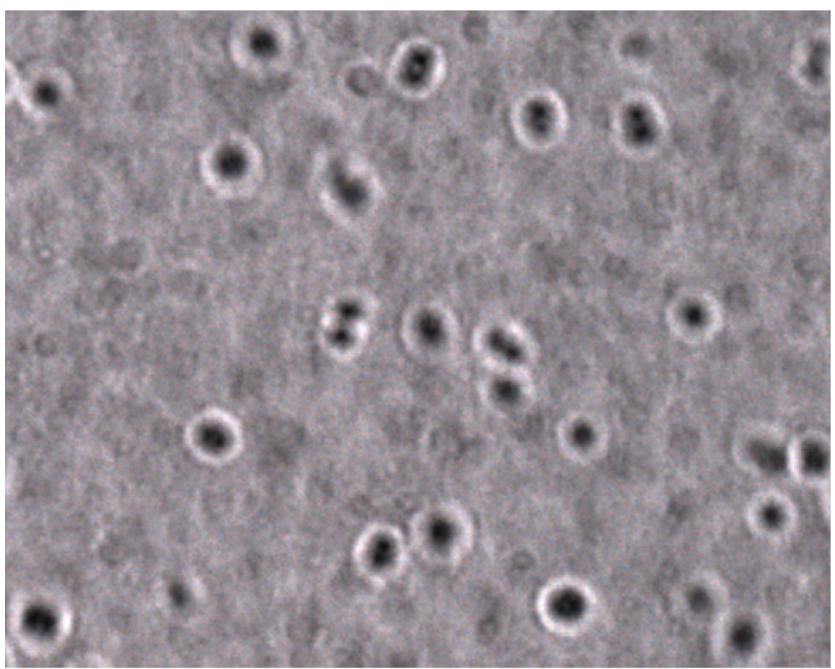

Figure 4. India ink capsule stain of $K$. massiliensis 


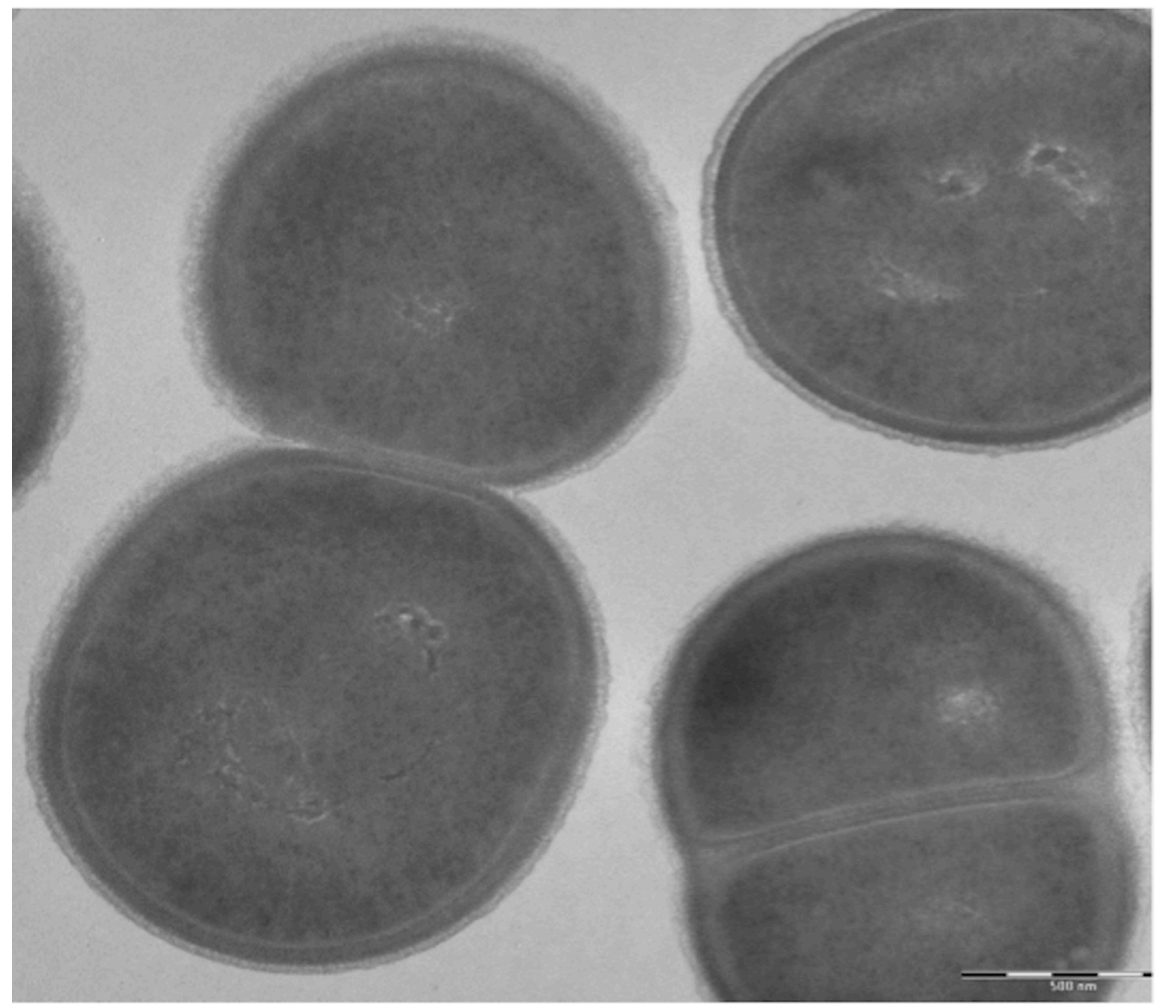

Figure 5. Capsule characterization of $K$. massiliensis after the bacteria were embedded in Epon 812 resin and observed by transmission electron microscopy.

Table 2. Differential phenotypic characteristics between strain $\mathrm{JC}^{\mathrm{C}} 30^{\top}$ and related species

\begin{tabular}{lllll}
\hline Characteristic & $\mathbf{1}$ & $\mathbf{2}$ & $\mathbf{3}$ & $\mathbf{4}$ \\
\hline gelatin hydrolysis & + & - & - & - \\
N-acetyl-glucosamine assimilation & - & - & + & - \\
D-maltose assimilation & + & - & - & - \\
potassium gluconate assimilation & + & - & - & - \\
trisodium citrate assimilation & + & - & - & - \\
alkaline phosphatase & - & + & $\mathrm{w}$ & + \\
esterase (C4) & + & + & $\mathrm{w}$ & $\mathrm{w}$ \\
esterase lipase (C8) & + & + & $\mathrm{w}$ & $\mathrm{w}$ \\
valine arylaminidase & $\mathrm{w}$ & - & + & - \\
cystine arylaminidase & + & + & - & - \\
echemotrypsin & $\mathrm{w}$ & - & + & - \\
naphtol-AS-BI-phosphohydrolase & - & - & + & + \\
eglucosidase & + & - & - & - \\
\hline
\end{tabular}

Strains: 1, K. massiliensis sp. nov. JC30'; 2, K. gibsonii DSM 20636' ; 3, K. zopfii DSM $20580^{\top} ; 4$, K. sibirica DSM $4747^{\top}$.

+ : positive result, -: negative result, w: weak positive result 


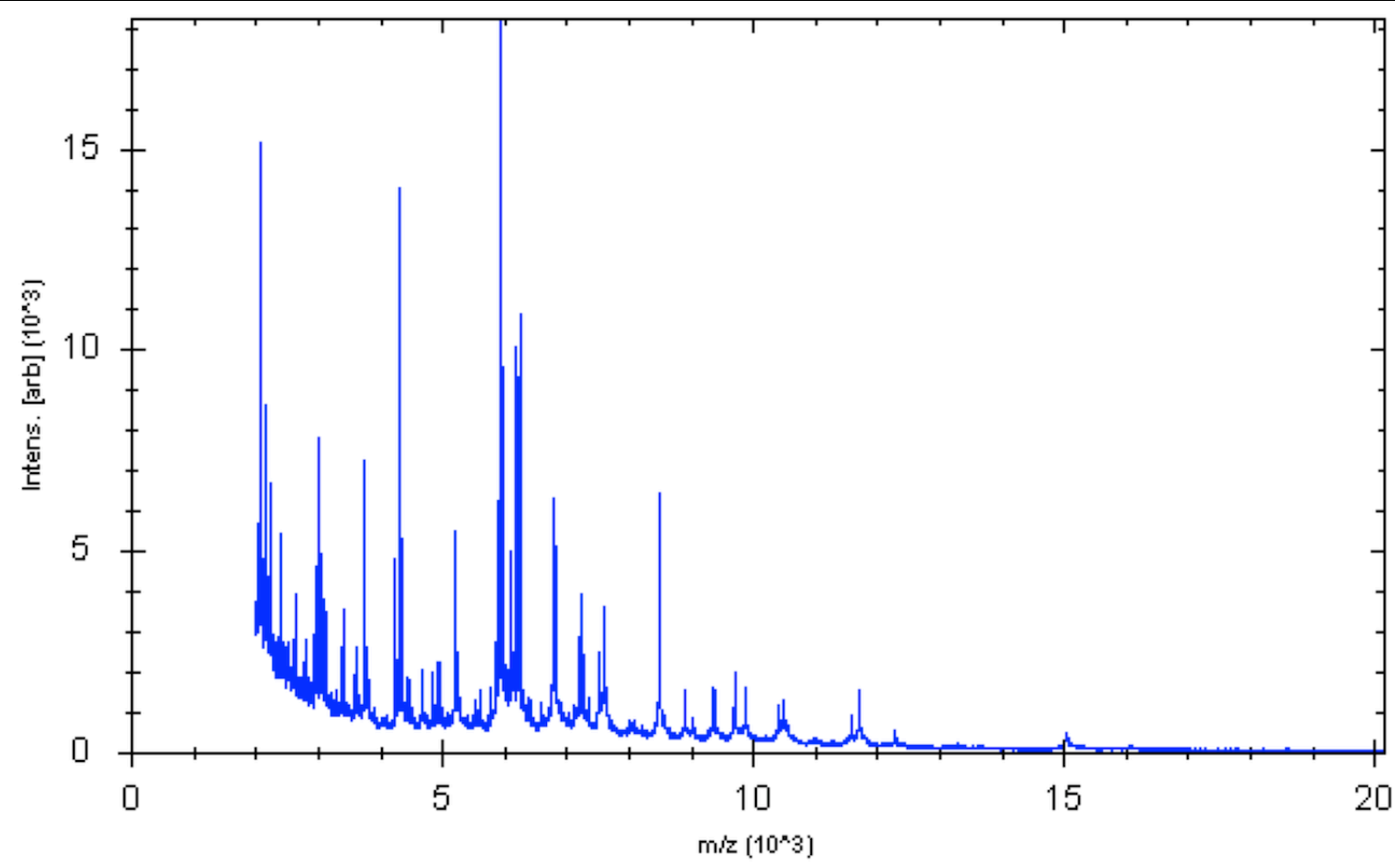

Figure 6. Reference mass spectrum from $K$. massiliensis strain $\mathrm{JC} 30^{\top}$. Spectra from 24 individual colonies were compared and a reference spectrum was generated.

\section{Genome sequencing information}

\section{Genome project history}

The organism was selected for sequencing on the basis of its phylogenetic position and 16S rRNA similarity to other members of the genus Kurthia, and is part of a "culturomics" study of the human digestive flora aiming at isolating all bacterial species within human feces. It was the first genome of a Kurthia species A summary of the project information is shown in Table 3. The EMBL accession number is CAEU01000000 and consists of 98 contigs ( $\geq 200 \mathrm{bp}$ ) and 18 scaffold ( $>2,424 \mathrm{bp}$ ). Table 3 shows the project information and its association with MIGS version 2.0 identifiers.

\section{Growth conditions and DNA isolation}

K. massiliensis sp. nov. strain JC30 ${ }^{\mathrm{T}}$, CSUR P141T, DSM 24639', was grown aerobically on 5\% sheep blood-enriched Columbia agar at $37^{\circ} \mathrm{C}$. Three petri dishes were spread and resuspended in $3 \times 100 \mu \mathrm{l}$ of G2 buffer. A first mechanical lysis was performed by glass powder on the Fastprep-24 device (Sample Preparation system) from MP Biomedicals, USA using $2 \times 20$ second cycles. DNA was then treated with lysozyme $(4.17 \mathrm{~g} / \mathrm{L}, 30$ minutes at $37^{\circ} \mathrm{C}$ ) and extracted through the BioRobot EZ 1 Advanced XL (Qiagen). The DNA was then concentrated and purified on a Qiamp kit (Qiagen). The yield and the concentration were measured by the Quant-it Picogreen kit (Invitrogen) on the Genios Tecan fluorometer at $63.1 / \mu$.

\section{Genome sequencing and assembly}

Shotgun and 3-kb paired-end sequencing strategies were used. The shotgun library was constructed with 500 ng of DNA with the GS Rapid library Prep kit (Roche). For paired-end sequencing, $5 \mu \mathrm{g}$ of DNA was mechanically fragmented on a Hydroshear device (Digilab) with an enrichment size at 3-4 kb. The DNA fragmentation was visualized using the 2100 BioAnalyzer (Agilent) on a DNA labchip 7500 with an optimal size of $3.619 \mathrm{~kb}$. The library was constructed according to the 454 GS FLX Titanium paired-end protocol. Circularization and nebulization were performed and generated a pattern with an optimal size of $472 \mathrm{bp}$. After PCR amplification through 15 cycles followed by double size selection, the single stranded paired-end library was then quantified using the Genios fluorometer (Tecan) at $430 \mathrm{pg} / \mu \mathrm{L}$. The library concentration equivalence was calculated as $1.69 \mathrm{E}+09$ molecules $/ \mu \mathrm{L}$. The library was stored at $-20^{\circ} \mathrm{C}$ until further use. 
Table 3. Project information

\begin{tabular}{lll}
\hline MIGS ID & Property & Term \\
\hline MIGS-31 & Finishing quality & High-quality draft \\
MIGS-28 & Libraries used & One paired end 3-kb library and one Shotgun library \\
MIGS-29 & Sequencing platforms & 454 GS FLX Titanium \\
MIGS-31.2 & Fold coverage & $22 \times$ \\
MIGS-30 & Assemblers & Newbler version 2.5.3 \\
MIGS-32 & Gene calling method & Prodigal \\
& EMBL ID & CAEU01000000 \\
& EMBL Date of Release & February 12, 2012 \\
& Project relevance & Study of the human gut microbiome \\
\hline
\end{tabular}

The shotgun and paired-end libraries were clonallyamplified with $3 \mathrm{cpb}$ and $1 \mathrm{cpb}$ in 3 and 4 emPCR reactions respectively on the GS Titanium SV emPCR Kit (Lib-L) v2 (Roche). The yields of the emPCR were 18.65 and $14.31 \%$ respectively. Approximately 340,000 beads for the shotgun sequencing and 790,000 beads for the $3 \mathrm{~kb}$ paired end sequencing were loaded onto the GS Titanium PicoTiterPlate PTP Kit 70×75 and sequenced with the GS FLX Titanium Sequencing Kit XLR70 (Roche). The run was performed overnight and then analyzed on the cluster through the gsRunBrowser and Newbler assembler (Roche). A total of 294,263 passed filter wells were obtained and generated $81.3 \mathrm{Mb}$ with a length average of $301 \mathrm{bp}$. The passed filter sequences were assembled using Newbler with $90 \%$ identity and 40 bp as overlap. The final assembly identified 18 scaffolds and 72 large contigs ( $>1,500 \mathrm{bp}$ ).

\section{Genome annotation}

Coding sequences (CDSs) were predicted using PRODIGAL with default parameters [30]. The functional annotation of protein sequences was per- formed against the non-redundant GenBank database using BLASTP. Functional categories of these proteins were searched against the Clusters of Orthologous Groups (COG) database using COGNITOR [31]. The prediction of RNAs genes, i.e., rRNAs, tRNAs and other RNAs was carried out using RNAmmer [32] and ARAGORN [33] algorithms. The transmembrane segments and peptide signals were identified using TMHMM [34] and SignalP tools [35].

\section{Genome properties}

The genome is $3,199,090 \mathrm{bp}$ long with a $39.26 \%$ GC content (Table 4, Figure 7). Of the 3,326 predicted genes, 3,240 were protein-coding genes, and 86 were RNAs. A total of 2,425 genes (74.8\%) were assigned a putative function. The remaining genes were annotated as either hypothetical proteins or proteins of unknown functions. The distribution of genes into COGs functional categories is presented in Table 5 . The properties and the statistics of the genome are summarized in Tables 4 and 5.

Table 4. Nucleotide content and gene count levels of the genome

\begin{tabular}{lrr}
\hline Attribute & Value & \% of total \\
\hline Genome size (bp) & $3,199,090$ & \\
DNA coding region (bp) & $2,794,828$ & 87.4 \\
DNA G+C content (bp) & $1,255,894$ & 39.26 \\
Total genes & 3,326 & 100 \\
RNA genes & 86 & 2.6 \\
Protein-coding genes & 3,240 & 97.4 \\
Genes with function prediction & 2,425 & 74.8 \\
Genes assigned to COGs & 2,500 & 77.16 \\
Genes with peptide signals & 269 & 8.3 \\
Genes with transmembrane helices & 473 & 14.6 \\
\hline
\end{tabular}

a) The total is based on either the size of the genome in base pairs or the total number of protein coding genes in the annotated genome. 


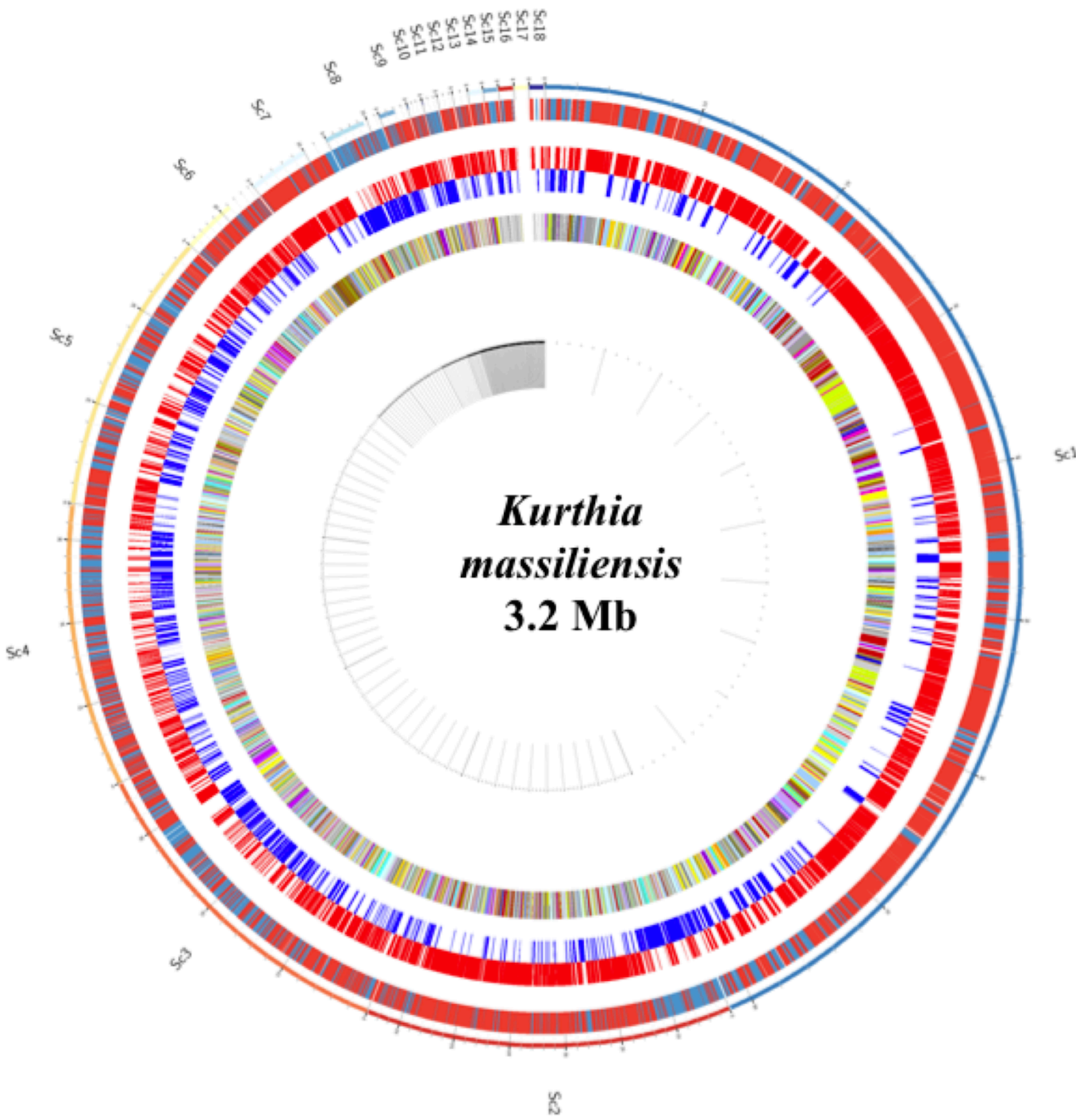

Figure 7. Graphical circular map of Kurthia massiliensis genome. From outside to the center: Genes on both strands, genes on foward strand, genes on reverse strand and genes colored by COG categories. 
Table 5. Number of genes associated with the 25 general COG functional categories

\begin{tabular}{|c|c|c|c|}
\hline Code & Value & \%age & Description \\
\hline$J$ & 161 & 4.97 & Translation \\
\hline A & 0 & 0 & RNA processing and modification \\
\hline K & 218 & 6.73 & Transcription \\
\hline $\mathrm{L}$ & 184 & 5.68 & Replication, recombination and repair \\
\hline B & 1 & 0.03 & Chromatin structure and dynamics \\
\hline $\mathrm{D}$ & 34 & 1.05 & Cell cycle control, mitosis and meiosis \\
\hline Y & 0 & 0 & Nuclear structure \\
\hline $\mathrm{V}$ & 47 & 1.45 & Defense mechanisms \\
\hline $\mathrm{T}$ & 171 & 5.28 & Signal transduction mechanisms \\
\hline M & 118 & 3.64 & Cell wall/membrane biogenesis \\
\hline $\mathrm{N}$ & 82 & 2.53 & Cell motility \\
\hline Z & 0 & 0 & Cytoskeleton \\
\hline W & 0 & 0 & Extracellular structures \\
\hline$U$ & 43 & 1.33 & Intracellular trafficking and secretion \\
\hline $\mathrm{O}$ & 92 & 2.84 & Posttranslational modification, protein turnover, chaperones \\
\hline $\mathrm{C}$ & 139 & 4.29 & Energy production and conversion \\
\hline G & 134 & 4.14 & Carbohydrate transport and metabolism \\
\hline $\mathrm{E}$ & 267 & 8.24 & Amino acid transport and metabolism \\
\hline $\mathrm{F}$ & 74 & 2.28 & Nucleotide transport and metabolism \\
\hline $\mathrm{H}$ & 134 & 4.14 & Coenzyme transport and metabolism \\
\hline I & 110 & 3.40 & Lipid transport and metabolism \\
\hline$P$ & 204 & 6.30 & Inorganic ion transport and metabolism \\
\hline Q & 68 & 2.10 & Secondary metabolites biosynthesis, transport and catabolism \\
\hline $\mathrm{R}$ & 402 & 12.41 & General function prediction only \\
\hline S & 237 & 7.31 & Function unknown \\
\hline$x$ & 740 & 22.84 & Not in COGs \\
\hline
\end{tabular}

The total is based on the total number of protein coding genes in the annotated genome. 


\section{Comparison with other Kurthia genomes}

To date, no genome of other strains or species belonging to the genus Kurthia were sequenced.

\section{Conclusion}

On the basis of phenotypic, phylogenetic and genomic analyses, we formally propose the creation of Kurthia massiliensis sp. nov., which contains the strain JC30T. This bacterium was found in Senegal.

\section{Description of Kurthia massiliensis sp. nov.}

Kurthia massiliensis (mas.si.li.en'sis. L. masc. adj. massiliensis of Massilia, the old Roman name for Marseille, where the type strain was isolated). Isolated from stool of a healthy Senegalese patient. $K$ massiliensis are aerobic Gram-positive coccobacilli. On sheep blood agar after $24 \mathrm{~h}$ aerobic incubation at $37^{\circ} \mathrm{C}$, colonies of strain $\mathrm{JC}^{\mathrm{T}}$ are circular, greyish/yellowish, shiny, curved and smooth, 2-5 $\mathrm{mm}$ in diameter. Cells are motile by peritrichous flagella and encapsulated. Catalase activity is positive but

\section{References}

1. Rossello-Mora R. DNA-DNA reassociation methods applied to microbial taxonomy and their critical evaluation. In: Stackebrandt E (ed), Molecular Identification, Systematics, and population Structure of Prokaryotes, Springer, Berlin, 2006, p. 2350.

2. Wayne LG, Brenner DJ, Colwell RR, Grimont PAD, Kandler O, Krichevsky MI, Moore LH, Moore WEC, Murray RGE, Stackebrandt E, et al. Report of the ad hoc committee on reconciliation of approaches to bacterial systematics. Int I Syst Bacteriol 1987; 37:463-464. http://dx.doi.org/10.1099/00207713-37-4-463

3. Tindall BJ, Rossello-Mora R, Busse HJ, Ludwig W, Kämpfer P. Notes on the characterization of prokaryote strains for taxonomic purposes. Int J Syst Evol Microbiol 2010; 60:249-266. PubMed http://dx.doi.org/10.1099/ijs.0.016949-0

4. Trevisan V. Caretteri di alcuni nuovi generi di Batteriacee. Atti della Accademia Fisio-MedicoStatistica in Milano, Series 4 1985; 3:92-107.

5. Breed RS, Murray EGD, Smith NR, eds. Bergey's Manual of Determinative Bacteriology, $7^{\text {th }}$ ed. Williams and Wilkins. Baltimore, MD. 1957.

6. Skerman VBD, McGowan V, Sneath PHA. Approved Lists of Bacterial Names. Int J Syst oxidase activity is negative. Gelatine hydrolysis, maltose assimilation, potassium gluconate assimilation, malic acid assimilation, trisodium citrate assimilation are present. Esterase (C4), esterase lipase (C8), cystine arylaminidase, $\alpha$-gluconidase activities are observed. Valine arylaminidase and alpha-chemotrypsin activities are weakly positive. The major fatty acids are iso $\mathrm{C}_{15: 0} \quad 68.04 \%$ and anteiso C15:0 16.92\%. Polar lipids found are diphosphatidylglycerol, phosphatidylglycerol, phosphatidylethanolamine, and phospholipid 1. The peptidoglycan type is A $4 \alpha \mathrm{L}$-Lys $\leftarrow \mathrm{D}$-Glu (type A11.33 according to [36]). Cells are susceptible to penicillin G, amoxicillin, amoxicillin + clavulanic acid, imipenem, gentamycin, erythromycin, doxycycline, rifampicin, vancomycin and nitrofurantoin. The $\mathrm{G}+\mathrm{C}$ content of the genome is $39.26 \%$. The type strain is JC30 $0^{\mathrm{T}}=$ CSUR P $141^{\mathrm{T}}=$ DSM 24639').

Bacteriol 1980; 30:225-420. http://dx.doi.org/10.1099/00207713-30-1-225

7. Keddie RM, Shaw S. Genus Kurthia. In: Sneath PHA, Mair NS, Sharpe ME and Holt JG (Eds.) Bergey's Manual of Systematic Bacteriology. Volume 2, The Williams and Wilkins Co., Baltimore,1986, p. 1255-1258.

8. Belikova VA, Cherevach NV, Kalakutskii LV. A new species of bacteria of the genus Kurthia, Kurthia sibirica sp. nov. Mikrobiologiya 1986; 55:831-835. PubMed

9. Field D, Garrity G, Gray T, Morrison N, Selengut J, Sterk P, Tatusova T, Thomson N, Allen MJ, Angiuoli SV, et al. The minimum information about a genome sequence (MIGS) specification. Nat Biotechnol 2008; 26:541-547. PubMed http://dx.doi.org/10.1038/nbt1360

10. Woese CR, Kandler O, Wheelis ML. Towards a natural system of organisms: proposal for the domains Archaea, Bacteria, and Eucarya. Proc Natl Acad Sci USA 1990; 87:4576-4579. PubMed http://dx.doi.org/10.1073/pnas.87.12.4576

11. Murray RGE. The Higher Taxa, or, a Place for Everything...? In: Holt JG (ed), Bergey's Manual of Systematic Bacteriology, First Edition, Volume 1, The Williams and Wilkins Co., Baltimore, 1984, p. 31-34. 
Roux et al.

12. Garrity GM, Holt JG. The Road Map to the Manual. In: Garrity GM, Boone DR, Castenholz RW (eds), Bergey's Manual of Systematic Bacteriology, Second Edition, Volume 1, Springer, New York, 2001, p. 119-169.

13. Ludwig W, Schleifer KH, Whitman WB. Class I. Bacilli class nov. In: De Vos P, Garrity G, Jones D, Krieg NR, Ludwig W, Rainey FA, Schleifer KH, Whitman WB (eds), Bergey's Manual of Systematic Bacteriology, Second Edition, Volume 3, Springer-Verlag, New York, 2009, p. 19-20.

14. List of new names and new combinations previously effectively, but not validly, published. List no. 132. Int / Syst Evol Microbiol 2010; 60:469472. http://dx.doi.org/10.1099/ijs.0.022855-0

15. Prévot AR. In: Hauderoy P, Ehringer G, Guillot G, Magrou. J., Prévot AR, Rosset D, Urbain A (eds), Dictionnaire des Bactéries Pathogènes, Second Edition, Masson et Cie, Paris, 1953, p. 1-692.

16. Krasil'nikov NA. Guide to the Bacteria and Actinomycetes [Opredelitelv Bakterii i Actinomicetov], Akad. Nauk SSSR, Moscow, 1949, p. 328.

17. Keddie RM, Rogosa M. Genus Kurthia Trevisan 1885, 92; Nom. cons. Opin. 13, Jud. Comm. 1954, 152. In: Buchanan RE, Gibbons NE (eds), Bergey's Manual of Determinative Bacteriology, Eighth Edition, The Williams and Wilkins Co., Baltimore, 1974, p. 631-632.

18. Judicial Commission. Opinions 4, 6, 7, 8, 9, 10, 11, 12, 13, 14. Opinion 13. Int Bull Bacteriol Nomencl Taxon 1954; 4:141-158.

19. Ashburner M, Ball CA, Blake JA, Botstein D, Butler $\mathrm{H}$, Cherry JM, Davis AP, Dolinski K, Dwight SS, Eppig JT, et al. Gene ontology: tool for the unification of biology. The Gene Ontology Consortium. Nat Genet 2000; 25:25-29. PubMed http://dx.doi.org/10.1038/75556

20. Tamura K, Peterson D, Peterson N, Stecher G, Nei M, Kumar S. MEGA5: Molecular Evolutionary Genetics Analysis using Maximum Likelihood, Evolutionary Distance, and Maximum Parsimony Methods. Mol Biol Evol 2011; 28:2731-2739. $\underline{\text { PubMed }}$ http://dx.doi.org/10.1093/molbev/msr121

21. Stackebrandt E, Ebers J. Taxonomic parameters revisited: tarnished gold standards. Microbiol Today 2006; 33:152-155.

22. Tindall BJ. A comparative study of the lipid composition of Halobacterium saccharovorum from various sources. Syst Appl Microbiol 1990;
13:128-130. http://dx.doi.org/10.1016/S07232020(11)80158-X

23. Tindall BJ. Lipid composition of Halobacterium lacusprofundi. FEMS Microbiol Lett 1990; 66:199202. http://dx.doi.org/10.1111/j.15746968.1990.tb03996.x

24. Bligh EG, Dyer WJ. A rapid method of total lipid extraction and purification. Can J Biochem Physiol 1959; 37:911-917. PubMed http://dx.doi.org/10.1139/o59-099

25. Tindall BJ, Sikorski J, Smibert RM, Kreig NR. Phenotypic characterization and the principles of comparative systematics. In: Reddy CA, Beveridge TJ, Breznak JA, Marzluf G, Schmidt TM, Snyder LR (eds), Methods for General and Molecular Microbiology, $3^{\text {rd }}$ edition, ASM Press, Washington, 2007, p. 330-393.

26. Schleifer KH. Analysis of the chemical composition and primary structure of murein. Methods Microbiol 1985; 18:123-156. http://dx.doi.org/10.1016/S0580-9517(08)70474$\underline{4}$

27. Schleifer KH, Kandler O. Peptidoglycan types of bacterial cell walls and their taxonomic implications. Bacteriol Rev 1972; 36:407-477. PubMed

28. MacKenzie SL. Gas chromatography analysis of amino acids as the $\mathrm{N}$-heptafluorobutyryl isobutyl esters. J Assoc Off Anal Chem 1987; 70:151-160. PubMed

29. URMS. http://ifr48.timone.univmrs.fr/portail2/index.php?option=com_content\&ta $\underline{\text { sk}=\text { view } \& i d=97 \& \text { Itemid }=54}$

30. Prodigal. http://prodigal.ornl.gov

31. Tatusov RL, Galperin MY, Natale DA, Koonin EV. The COG database: a tool for genome-scale analysis of protein functions and evolution. Nucleic Acids Res 2000; 28:33-36. PubMed http://dx.doi.org/10.1093/nar/28.1.33

32. Lagesen $K$, Hallin $P$, Rodland EA, Staerfeldt $H H$, Rognes T, Ussery DW. RNAmmer: consistent and rapid annotation of ribosomal RNA genes. Nucleic Acids Res 2007; 35:3100-3108. PubMed http://dx.doi.org/10.1093/nar/gkm160

33. Laslett D, Canback B. ARAGORN, a program to detect tRNA genes and tmRNA genes in nucleotide sequences. Nucleic Acids Res 2004; 32:1116. PubMed http://dx.doi.org/10.1093/nar/gkh152

34. TMHMM.

http://www.cbs.dtu.dk/services/TMHMM 
35. Petersen TN, Brunak S, von Heijne G, Nielsen H. SignalP 4.0. discriminating signal peptides from transmembrane regions. Nat Methods 2011;

8:785-786. PubMed

http://dx.doi.org/10.1038/nmeth.1701 36.http://www.dsmz.de/microorganisms/main.php?con tent id=35 